\title{
PEMANFAATAN LAHAN TIDUR UNTUK MENINGKATKAN USAHA PERTANIAN DI KELURAHAN WALIAN SATU KOTA TOMOHON
}

\author{
Grace A. J. Rumagit \\ Melsje Yellie Memah
}

\begin{abstract}
The purpose of the Community Partnership Program (PKM) in utilizing of idle land to increase agricultural business is to improve community welfare through diversification of agricultural businesses on idle land. This research was conducted in Walian Satu Village, South Tomohon Subdistrict, Tomohon City, for 10 months from February to November 2018 at Wawo farmer groups and Sapa farmer groups, each with 5 members so that the total members were 10 people. Criteria for achieving community partnership program activities (PKM) are: (1) land processing skills, (2) number and quality of production, (3) marketing, (4) income of group members, and (5) institutions and management. The results achieved through the community partnership program (PKM) are (1) increasing knowledge and skills of farmer group members in managing land. The expertise and knowledge possessed by farmer groups now has increased and has an effect on productivity and agricultural products, (2) intensive farming extention and supporting carried out by the team makes farmer groups experience increased insight in farming to be more increasing, both in its number and quality. (3) Limitations in funding make farmers difficult to manage land and choose to find other jobs. However with the funding from DP2M DIKTI, land management can be done well and farmer groups can develop their agricultural businesses and marketing. (4) Obstacles in cultivating of land and the desire to change professions are no longer the main thing due to various assistance in the form of seeds, agricultural equipment, funding, farming extention and supporting by the PKM team to develop agricultural businesses so that their income increases. (5) Debriefing knowledge about management and group institutions makes farmer groups better able to manage their farming. *jnkd*.
\end{abstract}

Keywords: utilization, idle land, agricultural business, Walian Satu Urban Village, Tomohon City

Tujuan dilakukannya kegiatan Program Kemitraan Masyarakat (PKM) tentang pemanfaatan lahan tidur untuk meningkatkan usaha pertanian melalui peningkatan kesejahteraan masyarakat melalui diversifikasi usaha pertanian pada lahan tidur. Penelitian ini dilakukan di Kelurahan Walian Satu, Kecamatan Tomohon Selatan, Kota Tomohon, selama 10 bulan dari bulan Februari sampai November 2018 pada kelompok tani Wawo dan kelompok tani Sapa masing-masing dengan jumlah anggota 5 orang sehingga total anggota sebanyak 10 orang. Kriteria pencapaian kegiatan program kemitraan masyarakat (PKM) yaitu : (1) keterampilan mengolah lahan, (2) jumlah dan kualitas produksi, (3) pemasaran, (4) pendapatan anggota kelompok, dan (5) kelembagaan dan manajemen. Hasil yang dicapai melalui program kemitraan masyarakat (PKM) adalah (1) peningkatan pengetahuan dan keterampilan anggota kelompok tani dalam mengelola lahan. Keahlian dan pengetahuan yang dimiliki oleh kelompok tani saat ini sudah meningkat dan berpengaruh terhadap produktivitas serta hasil pertanian, (2) penyuluhan dan pendampingan intensif yang di lakukan oleh tim membuat kelompok tani mengalami peningkatan wawasan dalam bertani menjadi lebih meningkat, baik jumlah maupun kualitasnya, (3) keterbatasan dalam pendanaan membuat petani terhambat untuk mengelola lahan dan memilih untuk mencari pekerjaan lain. Tetapi dengan adanya bantuan pendanaan dari DP2M DIKTI membuat pengolahan lahan dapat terlaksana dengan baik dan kelompok tani bisa mengembangkan usaha pertanian dan pemasarannya, (4) hambatan dalam mengolah lahan dan keinginan untuk beralih profesi bukan lagi menjadi hal yang utama dikarenakan adanya berbagai bantuan berupa bibit, peralatan pertanian, pendanaan, penyuluhan dan pendampingan oleh tim PKM untuk mengembangkan usaha pertanian sehingga pendapatannya meningkat, (5) Pembekalan pengetahuan tentang manajemen dan kelembagaan kelompok membuat kelompok tani mampu mengelola usahataninya dengan lebih baik. *eprm*.

Kata kunci: pemanfaatan, lahan tidur, usaha pertanian, Kelurahan Walian Satu, Kota Tomohon

Agrisosioekonomi:

Jurnal Transdisiplin Pertanian (Budidaya Tanaman, Perkebunan, Kehutanan, Peternakan, Perikanan), Sosial dan Ekonomi 


\section{PENDAHULUAN}

\section{Analisis Situasi}

Perkembangan zaman saat ini mempengaruhi berkembangnya kebutuhan pada masyarakat, menuntut masyarakat memperhatikan perubahan yang terjadi sebagai dampak berubahnya pola pikir manusia yang terus berkembang pula. Bidang Ekonomi menjadi satu perhatian yang difokuskan oleh masyarakat untuk berkembang. Karena perubahan ekonomi yang dipacu oleh kebutuhan manusia yang semakin meningkat harus diimbangi dengan pendapatan yang meningkat lebih tinggi. Namun masyarakat mengalami kesulitan yang diakibatkan oleh keterbatasan sumberdaya yang mereka miliki, hal ini menciptakan permasalahan ekonomi masyarakat berupa ketidak seimbangan antara pengeluaran dan pendapatan ekonomi masyarakat sehingga muncullah permasalahan ekonomi dalam masyarakat.

Ekonomi rakyat merupakan segala jenis upaya masyarakat dalam memenuhi segala macam kebutuhan hidupnya dari sandang, pangan, papan, pendidikan, kesehatan. Upaya masyarakat tersebut direalisasikan dengan cara kegiatan yang menghasilkan bagi diri masyarakat sendiri secara swadaya dengan mengolah sumber daya yang ada untuk diambil hasilnya.

Kelurahan Walian Satu Kota Tomohon adalah Lokasi yang dipilih untuk Memberdayakan masyarakat dalam pemanfaatan lahan tidur untuk peningkatan usaha pertanian sehingga dapat mendorong kesejahteraan masyarakat setempat. Kelurahan Walian Satu merupakan salah satu Kelurahan di Kecamatan Tomohon selatan yang berjarak sekitar $30 \mathrm{~km}$ dari Kota Manado, ibukota Propinsi Sulawesi Utara. Memiliki topografi wilayah lereng dan dataran dengan ketinggian 820 meter dari permukaan laut. Letak astronomisnya adalah 1018 ' - 1027' Lintang Utara dan 111040' - 124055' Bujur Timur. Luas Kelurahan Walian Sua ini adalah 0,9640 $\mathrm{Km} 2$. Kelurahan ini pada umumnya beriklim sejuk dengan temperatur berkisar antara $180 \mathrm{C}$ $-300 \mathrm{C}$.
Tahun 2015 jumlah penduduk Kelurahan Walian Satu berjumlah 1573 jiwa dengan mayoritas penduduk berprofesi sebagai petani. Peningkatan mutu pendidikan yang belum memadai, hal ini tercermin dari tidak tersedianya sarana sekolah seperti TK, SD, SLTP, SLTA dikelurahan ini, masyarakat harus bersekolah dikelurahan yang lain untuk menempu jalur pendidikan. Untuk bidang kesehatan tidak tersedia puskesmas, poskesdes ataupun rumah sakit, yang ada hanya 1 PKM pembantu. Penduduk di kelurahan ini mayoritas beragama Kristen. Sedangkan untuk luas Pemukiman Kelurahan Walian Satu 17,5 Ha dengan luas kebun 78,9 Ha.

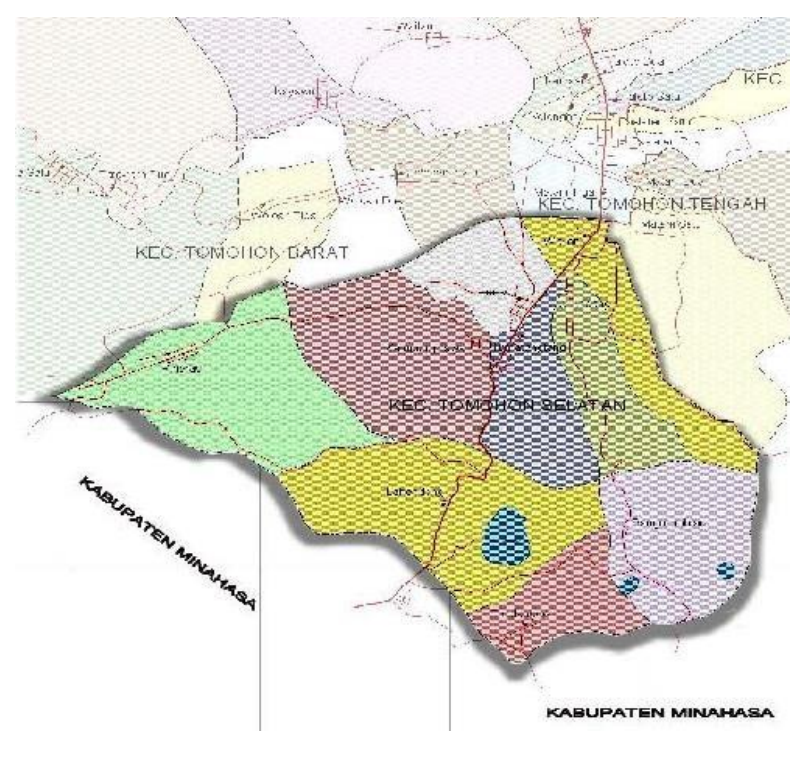

Gambar 1. Peta Kecamatan Tomohon Selatan

Sumber: Data Peta Google Indonesia, 2017

Berdasarkan observasi awal yang dilakukan, saat ini masyarakat tidak lagi menganggap pertanian sebagai sebuah mata pencaharian yang menguntungkan yang pada akhirnya beralih dan meninggalkan lahannya. Pemanfaat lahan tidur disertai dengan perbaikan pola tanam dengan diversifikasi komoditas dapat memperkaya jenis sumber penghasilan Petani sehingga nantinya bisa mendapatkan penghasilan. Banyaknya lahan yang tidak dikelola padahal bisa produktif tentunya menjadi perhatian khusus untuk mendorong masyarakat mengolah tanah mereka sehingga bisa meningkatkan kesejahteraan masyarakat. 
Pertanian secara alamiah sangat dibutuhkan untuk menopang kehidupan dan kelangsungan ekosistem masyarakat. Sebagai sektor kehidupan pertanian dibutuhkan oleh keseluruhan masyarakat. Di zaman yang semakin modern ini tidak dipungkiri para generasi muda lebih memilih bekerja di bidang industri dan perkantoran daripada bekerja di bidang pertanian, hal ini menyebabkan daerah pedesaan yang bergerak di bidang pertanian kekurangan tenaga produktif. Selain itu, semakin meningkatnya biaya operasional dalam pengolahan lahan pertanian juga menyebabkan para petani mengalami kerugian, sehingga mereka lebih memilih untuk beralih profesi.

Tabel 1 dibawah ini terlihat harga sayuran yang ada di pasar menurut Pusat Informasi Harga Bahan Pokok Strategis (PIHBS) Sulawesi Utara. Jika dilihat harga sayuran yang semakin mahal menandakan adanya peningkatan peluang pertumbuhan kesejahteraan petani. Pertumbuhan kesejahteraan petani dapat dilakukan dengan pemanfaatan dan pengelolaan sumber daya secara tapat dan maksimal.

Tabel 1. Harga Sayuran di Pasaran

\begin{tabular}{clcc}
\hline No. & Bahan Pokok & Satuan & Harga (Rp) \\
\hline 1 & Cabe Merah Keriting & Rp./Kg & 23.554 \\
2 & Cabe Rawit & Rp./Kg & 59.161 \\
3 & Bawang Merah & Rp./Kg & 37.054 \\
4 & Bawang Putih & Rp./Kg & 52.571 \\
5 & Tomat Sayur & Rp./Kg & 11.000 \\
\hline
\end{tabular}

Sumber : PIHBS Sulawesi Utara

Potensi yang bisa dikembangkan Kelompok Tani sesungguhnya sangat prospektif. Luas lahan yang bisa digunakan kelompok ini sekitar 1 hektar. Jika dimanfaatkan dengan baik lahan tersebut saat ini dapat ditanami cabe rawit, bawang, dan jagung. Alasan kekurangan modal dan harga sayuran di pasar yang relatif murah ditambah dengan banyaknya hama penyakit yang dapat menyerang tanaman menjadi faktor penghambat kegiatan produksi para anggota kelompok tani. Selain itu lahan ini tidak diairi oleh pengairan teknis yang ada dan lebih banyak mengandalkan air hujan, oleh karenanya petani harus menyiasatinya dengan membuatkan sumur pompa di lahan tersebut.
Potensi yang bisa dikembangkan Kelompok Tani sesungguhnya sangat prospektif. Luas lahan yang bisa digunakan kelompok ini sekitar 1 hektar. Jika dimanfaatkan dengan baik lahan tersebut saat ini dapat ditanami cabe rawit, bawang, dan jagung. Alasan kekurangan modal dan harga sayuran di pasar yang relatif murah ditambah dengan banyaknya hama penyakit yang dapat menyerang tanaman menjadi faktor penghambat kegiatan produksi para anggota kelompok tani. Selain itu lahan ini tidak diairi oleh pengairan teknis yang ada dan lebih banyak mengandalkan air hujan, oleh karenanya petani harus menyiasatinya dengan membuatkan sumur pompa di lahan tersebut.

Letak lokasi Walian Satu sangat strategis, karena daerah ini dapat menjadi pemasok untuk daerah Tondano, Manado, Kawangkoan, dan Minahasa Utara. Sedangkan dari sisi persaingan, hasil pertanian yang dihasilkan oleh kelompok masyarakat di kelurahan Walian Satu masih belum mampu menjadi pilihan utama dibandingkan dengan hasil pertanian yang berasal dari Kecamatan Modoinding Kabupaten Minahasa Selatan. Penyebabnya adalah karena bentuk pengelolaan di daerah tersebut sudah dilakukan secara menyeluruh dengan hasil produksi yang lebih banyak. Akibatnya hasil tanaman yang dihasilkan oleh Kelompok masyarakat di desa walian dua hanya menjadi pilihan kedua, yang berarti kurang menjanjikan dari sisi pendapatan petani. Oleh karena itu, harus dicarikan solusi dengan memanfaatkan lahan tidur yang ada.

Untuk sampai pada tahap itu, maka perencanaan dan pengelolaan di tingkat kelompok harus dilakukan. Bimbingan teknis dan pendampingan harus dilakukan untuk pemanfaatan potensi yang ada di sekitarnya. Potensi dimaksud adalah akan adanya pertumbuhan kesejahteraan kelompok tani. Hal ini menggambarkan bahwa sesungguhnya potensi yang ada bisa dimanfaatkan dan memiliki keterkaitan yang erat. Di satu sisi ada lahan yang bisa diolah, iklim yang cocok untuk bertani, ada kelompok masyarkat, dan adanya pendampingan Program Kemitraan Masyarakat. 
Melihat kondisi tersebut, yang dibutuhkan adalah mensinergikannya bentuk aksi yang lebih nyata untuk memfasilitasi sekaligus membekali mereka pengetahuan dan keterampilan yang bisa langsung diterapkan di tingkat kelompok masyarakat, sehingga pada akhirnya kemandirian ekonomi kelompok masyarakat di lokasi ini bisa terbangun. Oleh karena itu, keberadaan kegiatan Program Kemitraan Masyarakat (PKM) yang didanai oleh Ristekdikti menjadi sangat penting.

\section{Tujuan Program Kemitraan Masyarakat (PKM)}

Untuk meningkatkan kesejahteraan masyarakat melalui diversifikasi usaha pertanian pada lahan tidur di Kelurahan Walian Satu Kota Tomohon.

\section{METODE PELAKSANAAN}

Program ini merupakan program yang bersifat terapan dalam rangka peningkatan kesejahteraan masyarakat di Kelurahan Walian Satu Kota Tomohon. Meningkatnya kesejahteraan dalam bentuk bertambahnya pendapatan yang diperoleh anggota kelompok dari kegiatan Pemanfaatan lahan bermula dari proses transfer pengetahuan dan teknologi yang langsung bisa diaplikasikan di lapangan. Pengetahuan dan teknologi yang akan ditransfer pada kegiatan ini adalah teknik pengolahan lahan, peningkatan kuantitas dan kualitas tanaman, pencegahan hama penyakit, cara memasarkan hasil produksi pertanian, serta penyusunan pembukuan sederhana. Di dalam pelaksanaannya, program ini akan mengacu pada pola sinergis antara tenaga pakar dan praktisi dari Universitas Sam Ratulangi Manado dengan pemerintah Kelurahan Walian Satu Kota Tomohon.

Program ini juga dirancang agar tercipta sinergitas yang saling menguntungkan antara kelompok-kelompok tani yang ada di Kelurahan Walian Satu. Di sisi lain, program ini juga diarahkan agar terciptanya iklim kerjasama yang kolaboratif antara perguruan tinggi dengan masyarakat secara luas di bawah koordinasi pemerintah Kelurahan setempat, khususnya dalam rangka meningkatkan pengetahuan dan wawasan anggota kelompok tani Kelurahan Walian Satu secara cepat dan berkualitas bagi kepentingan pembangunan masyarakat setempat. Berdasarkan pemikiran tersebut, maka program ini merupakan sebuah langkah inovatif dalam kaitannya dengan Tri Dharma perguruan tinggi, yaitu salah satunya adalah pengabdian kepada masyarakat.

\section{Prosedur Tahapan Kegiatan}

Program ini dirancang sebagai bentuk jawaban dari permasalahan belum tersedianya sumberdaya manusia yang potensial dalam melakukan usahatani berupa pemanfaat lahan untuk peningkatan kesejahteraan petani. Nilai tambah yang diperoleh bukan saja dalam bentuk perbaikan lingkungan berupa kesuburan tanah yang semakin meningkat tetapi juga kualitas dan kuantitas produksi yang lebih baik dan pada akhirnya memberikan nilai tambah ekonomi yang lebih tinggi untuk menunjang kesejahteraan anggota kelompok. Melalui pelaksanaan program yang dirancang ini akan diberikan pelatihan dan pendampingan bagi anggota kelompok tani dengan materi pelatihan, diantaranya yaitu: pengolahan lahan, peningkatan kuantitas dan kualitas tanaman, pencegahan hama penyakit, strategi pemasaran, serta penyusunan pembukuan sederhana.

Lama pelaksanaan kegiatan adalah 10 (sepuluh) bulan yang dimulai dari tahap perencanaan, pelaksanaan sampai pada proses evaluasi dengan melibatkan seluruh anggota kelompok tani Wawo dan Kelompok tani Sapa di Kelurahan Walian Satu Kota Tomohon yang berjumlah 10 orang. Melalui program ini, diharapkan kelompok tani mendapatkan pengetahuan dan pemahaman yang jelas tentang pemanfaatan lahan tidur untuk meningkatkan usaha pertanian yang berkelanjutan.

\section{Evaluasi Kegiatan}

Untuk mengukur tingkat keberhasilan kegiatan yang telah dilakukan, maka akan dilakukan evaluasi proses, evaluasi akhir, dan evaluasi tindak lanjut sedangkan kegiatan terus dilakukan melalui kunjungan lapangan minimal 2 (dua) kali dalam sebulan untuk melihat aplikasi budidaya yang dilakukan kelompok tani. Untuk kegiatan evaluasi akan melibatkan tutor/pakar dari Universitas Sam Ratulangi Manado. Kriteria dan indikator 
pencapaian tujuan dan tolak ukur yang digunakan dalam tingkat keberhasilan kegiatan dapat diuraikan pada Tabel 2 berikut:

Tabel 2. Kriteria dan Indikator Pencapaian Kegiatan

\begin{tabular}{|c|c|c|c|}
\hline No. & Komponen & Sasaran & Indikator \\
\hline 1. & $\begin{array}{l}\text { Keterampilan } \\
\text { mengolah } \\
\text { lahan }\end{array}$ & Mitra & $\begin{array}{l}\text { Anggota kelompok } \\
\text { mampu mengolah } \\
\text { lahan mereka }\end{array}$ \\
\hline 2. & $\begin{array}{l}\text { Jumlah dan } \\
\text { kualitas } \\
\text { produksi }\end{array}$ & Mitra & $\begin{array}{l}\text { Jumlah produksi } \\
\text { meningkat dan kualitas } \\
\text { produk lebih baik }\end{array}$ \\
\hline 3. & Pemasaran & Mitra & $\begin{array}{l}\text { - Ada peningkatan } \\
\text { konsumen } \\
\text { - Ada jaringan } \\
\text { kemitraan } \\
\text { pemasaran }\end{array}$ \\
\hline 4. & $\begin{array}{l}\text { Pendapatan } \\
\text { anggota } \\
\text { kelompok }\end{array}$ & Mitra & $\begin{array}{l}\text { Pendapatan yang } \\
\text { diperoleh meningkat } \\
\text { dibanding se- } \\
\text { belumnya }\end{array}$ \\
\hline 5. & $\begin{array}{l}\text { Kelembagaan } \\
\text { dan } \\
\text { manajemen }\end{array}$ & Mitra & $\begin{array}{l}\text { - Administrasi } \\
\text { kelompok } \\
\text { - Pengelolaan } \\
\text { keuangan } \\
\text { - Terbentuk kelompok } \\
\text { usahatani }\end{array}$ \\
\hline
\end{tabular}

\section{HASIL YANG DICAPAI}

\section{Hasil Yang Dicapai}

1. Peningkatan pengetahuan dan pengelolaan usahatani dilakukan secara berkelompok melalui pelatihan dan bimbingan kepada kelompok tani yang berfokus pada materi untuk mendinamisasikan kelompok.

a. Kelompok tani sudah bisa merencanakan program: Rencana yang dimaksudkan adalah rencana bersama kelompok yang tertulis, yang harus dilaksanakan dalam jangka waktu tertentu. Perencanaan dimulai dengan proses menyusun rencana kerja untuk melakukan usahatani dan jenis tanaman yang akan di tanaman, cara pengelolaan tanah dan tanaman, perawatan tanaman, bagaimana memasarkan hasil pertanian ittu nantinya, serta mengembangkan rencana kerja kelompok dan peraturan dalam kelompok yang harus dilaksanakan secara bersama. Perencanaan penting untuk merencanakan perbaikan dalam kelompok ini, meningkatkan produksi dan meningkat-kan kerjasama serta meningkatkan pendapatan kelompok. Dalam memberikan penyuluhan tentang pengelolaan secara berkelompok tim PKM juga memberikan materi tentang cara menentukan sasaran program dalam kelompok untuk mencapai tujuan yang telah ditetapkan bersama. Sasaran yang baik memenuhi memenuhi kriteria:

1) Spesifik: Sasaran harus menggambarkan hasil spesifik yang diinginkan dan memberikan arah dan tolok ukur yang jelas.

2) Terukur: Sasaran harus terukur dan dapat dipergunakan untuk memastikan apa dan kapan pencapaiannya.

Target sasaran program yang diberikan adalah:

1) Penjualan hasil dari usaha pertanian di akhir tahun 2018 memperoleh keuntungan $40 \%$ dari biaya produksi

2) Pada tahun 2019 terjadi pengurangan gagal panen sebesar $20 \%$.

b. Kelompok tani sudah mampu mengelola program yang sudah di rencanakan: Penjabaran langkah-langkah serta sasaran program dan sub-program dibuat rinci sesuai dengan keperluan:

1) Kegiatan mana saja yang berpengaruh pada kegiatan berikutnya, maka kegiatan tersebut didahulukan. Untuk memahami tahap kegiataan selanjutnya, kelompok tani dibekali pengetahuan teknik dasar budidaya tanaman yang dimulai dengan proses pengolahan tanah $\rightarrow$ pemupukan $\rightarrow$ persemaian benih $\rightarrow$ penanaman $\rightarrow$ pemeliharaan tanaman $\rightarrow$ pengambilan hasil $\rightarrow$ pemasaran hasil $\rightarrow$ analisis usaha

2) Perhitungan waktu: berapa lama, kapan tepat dilaksanakan. (a) Cabai: Pada umumnya waktu panen rata-rata setelah berumur 2,5 bulan sampai 3 
bulan sesudah disemai, proses pesemaian cabai 1 bulan; (b) Jagung manis siap dipanen jika usia sudah memasuki 60 hari atau 2 bulan. Waktu umur tanaman jagung panen dilakukan setelah hari yang ke 63. Hal ini bertujuan agar jagung sudah terisi secara penuh dan maksimal. Pemanenan jagung jangan sampai melebihi 67 hari. Hal ini dapat mengurangi rasa manis dari jagung; (c) Daun Bawang bisa dipanen setelah berumur 2,5 bulan sejak bibit ditanam.

3) Siapa pelaksana dan penanggung jawab: Untuk menghindari ketidakaktifan kelompok maka perlu dibagi jadwal pelaksana dan penanggung jawab saat perawatan tanaman. Untuk proses pengolahan tanah dan penanaman serta pengambilan hasil dapat dilaksanakan bersama-sama.

4) Modal/anggaran: Berapa besar dana yang di butuhkan dalam melakuan usahatani. Perhitungan total biaya produksi yang dibutuhkan harus diperhitungan melalui analisis usaha (analisis laba-rugi).

c. Pengetahuan kelompok tani tentang cara mengevaluasi dan tindak lanjut terhadap program yang dikelola: Evaluasi berangkat dari kegiatan montoring setiap proses dalam usahatani yang dijalankan, dari hasil monitoring dapat dibuat analisis kemajuan, kemunduran dan pencapaian apa yang sudah dilaksanakan. Apa saja yang perlu dievaluasi?

1) Posisi Keseluruhan Usahatani.

2) Apakah Ada kemajuan atau Kemunduran dalam usaha tani ini?

3) Mengevalusi pasar sasaran

4) Menargetkan usahatani selanjutnya setelah PKM selesai dilaksanakan

2. Diversifikasi Pertanian atau penganeka ragaman jenis tanaman dalam satu lahan untuk menghindari resiko adanya fluktuasi harga komoditas pertanian serta ketergantungan pada satu hasil pertanian. Dengan pembagian tanaman sebagai berikut:

a. Cabai: jenis cabai yang digunakan adalah varietas FM malita karena tanaman ini dapat beradaptasi pada kondisi arkeologi sangat luas mulai dari ketinggian 5-1500 di atas permukaan laut, selain itu jenis cabai ini tahan terhadap cekaman lingkungan dan nilai jual yang lebih tinggi serta lebih mudah dipasarkan di Sulawesi Utara dibandingkan jenis cabai lainnya. Mengingat harga jual yang masih tinggi di pasaran, tanaman cabai ditanam dengan persentase yang lebih besar dibanding dua jenis tanaman lainnya.

b. Jagung manis: vairetas yang digunakan adalah jagung bonanza. Jenis varietas ini tahan terhadap serangan hama dan juga penyakit. Tanaman jagung manis ini tetap tahan terhadap serangan hama dan juga penyakit dan tahan terhadap cuaca yang berubah-ubah. Daya simpan Jagung ini lebih lama dibandingkan jenis jagung lainnya.

c. Daun bawang: daun bawang yang digunakan adalah jenis daun bawang lokal Tomohon

d. Selain ketiga komoditas yang di biayai oleh kegiatan ini, kelompok berinisiatif untuk menanam dua komoditas lain, yaitu bawang merah dan ubi jalar.

3. Peningkatan kualitas produksi. Capaian ini diperoleh dengan cara Intensifikasi yang disertai dengan pelatihan dan pendampingan, yaitu:

a. Perbaikan metode kerja dan penggunaan bibit unggul dalam kegiatan ini menggunakan bibit cabai FM malita, bibit jagung bonanza dan bibit daun bawang lokal

1) Cabai: Pengolahan lahan dimulai bersamaan dengan pembibitan. Saat benih cabai siap tanam, lahan juga siap untuk digunakan. Pembuatan bedengan dibuat dengan lebar sekitar 1-1,2 m dengan jarak tanam tanaman 
cabe $60 \mathrm{~cm} \times 50 \mathrm{~cm}$, setiap lubang dimasukkan pupuk dasar dan dibiarkan selama 3 hari untuk nantinya siap untuk ditanami. Penggunaan mulsa plastik untuk mempertahankan kelembapan, mengendalikan gulma dan menjaga kebersihan kebun. Pemindahan bibit cabe dilakukan setelah umur bibit sekitar 1 bulan atau bibit memiliki 3 4 helai daun permanen. Cara menanamnya adalah dengan memindahkan bibit beserta dengan tanah yang menempel pada perakaran kemudian masukkan ke dalam lubang tanam. Penyiraman dilakukan menggunaan selang panjang. Penyiraman dilakukan dengan hati hati disaat tanaman belum terlalu kuat.

2) Jagung: Pengolahan lahan diawali dengan membersihkan lahan dari sisa sisa tanaman sebelumnya. Kemudian dilanjutkan dengan pencangkulan dan pengolahan tanah dengan bajak. Setelah tanah diolah dibuat saluran drainase. Lebar saluran 25-30 cm. Jarak tanam $75 \times 25 \mathrm{~cm}$. Jumlah benih yang dimasukkan 2 biji per lubang.

3) Daun Bawang: Gali tanah hingga $30 \mathrm{~cm}$ dan gunakan pupuk dasar. Tahap selanjutnya adalah pembuatan bedengan, ukuran ukuran lebar $100 \mathrm{~cm}$, tinggi $30 \mathrm{~cm}$. Setelah itu buat lubang untuk penanaman bibit daun bawang dengan jarak $30 \mathrm{~cm}$ antar lubang.

1. Pemberantasan hama dan penyakit pada tanaman: telah diberikan oleh hama dan penyakit dari Universitas Sam Ratulangi.

2. Pengairan yang cukup. Kegiatan usahatani ini terkendala dengan musim kemarau panjang yang menyebabkan lahannya mengalami kekeringan. Solusi untuk mengatasi-nya adalah dengan menyiram tanaman. Setiap minggu dibutuhkan dua tangki air.
4. Peningkatan Pendapatan:

a) Cabai: Luas lahan cabai 0,3 hektar (25 $\mathrm{m} \times 120 \mathrm{~m}$ ). Untuk panen perdana, satu pohon menghasilkan $0,3 \mathrm{~kg}$ cabai, dengan jumlah tanaman cabai sebanyak 3960 Pohon, diperoleh $1.188 \mathrm{~kg}$ cabai. Harga cabai di tingkat petani sebesar Rp $30.000 / \mathrm{kg}$, maka penerimaan dari usahatani cabai sebesar Rp 35.460.000

b) Jagung: Luas Lahan jagung 0,2 hektar $(40 \mathrm{~m} \times 50 \mathrm{~m})$, diperoleh hasil 96 karung, dengan harga jagung di tingkat petani sebesar Rp. 100.000/karung, maka penerimaan dari usahatani jagung sebesar Rp 9.600.000

c) Daun Bawang : Luas lahan daun bawang 0,2 hektar (25 $\mathrm{m}$ x 40$)$, menghasilkan $750 \mathrm{~kg}$ daun bawang, harga daun bawang di tingkat petani sebesar Rp. 10.000/ikat, maka penerimaan dari usahatani daun bawang sebesar Rp 7.500.000.

5. Kelompok tani dapat membuat pembukuan sederhana dari hasil kegiatan usaha. Hasil perhitungan tersebut dapat memberikan informasi kepada kelompok tani mengenai total jumlah pengeluaran dan Pendapatan yang terjadi selama mengelola lahan.

6. Pemasaran Hasil Pertanian :

Pengetahuan dan keterampilan tentang pemasaran dan cara memasarkan produksi pertanian telah diberikan untuk meningkatkan kemampuan kepada kelompok tani, dengan cara:

1) Menjalin hubungan yang baik dengan konsumen

2) Menerapkan sistem jual beli produk pertaniannya secara online. Kelompok tani dapat berinteraksi dengan pembeli yang berada diluar daerah dengan sangat mudah. Pembekalan pengetahuan tentang pemasaran online dapat melalui sosial media (facebook dan Instagram).

3) Jaringan pemasaran tidak hanya menyasar pasar yang umum tetapi diajarkan cara bekerjasama dengan supermarket ataupun rumah makan/ restoran, dan hotel-hotel. 
Tabel 3. Hasil Perhitungan Mengenai Total Jumlah Pengeluaran Dan Pendapatan Yang Terjadi Selama Kegiatan PKM

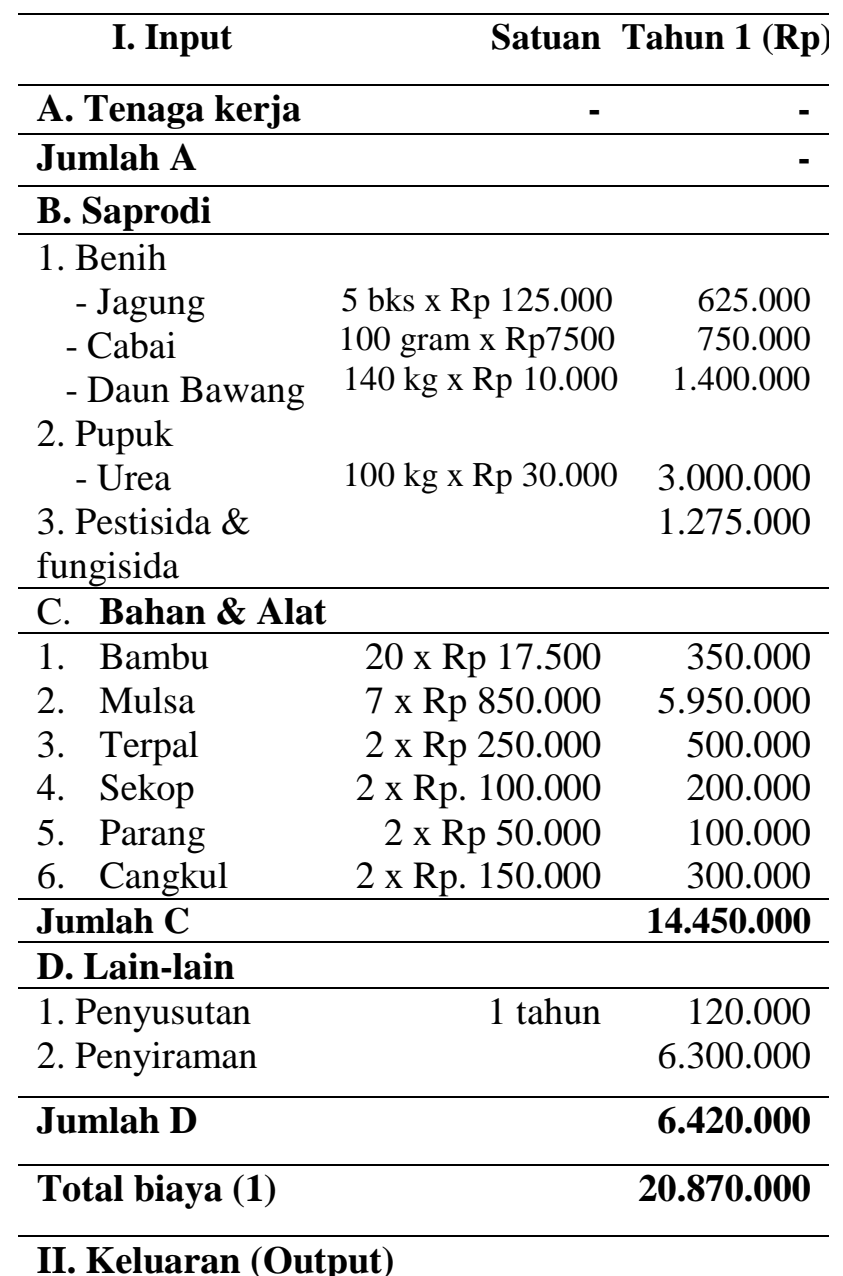

Total produksi
a) Cabai
$1188 \mathrm{Kg}$
b) Jagung
96 Karung
c) Daun Bawang
$750 \mathrm{Kg}$

Harga Jual
a) Cabai
$\mathrm{Rp} 30.000 / \mathrm{Kg}$
b) Jagung
Rp.100.000/karung
c) Daun Bawang
Rp. $11.000 / \mathrm{Kg}$
Nilai Total

Produksi (NTP)
a) Cabai
35.460 .000
b) Jagung
9.600 .000
c) DaunBawang
7.500 .000

\begin{tabular}{lr}
\hline Penerimaan (2) & $\mathbf{5 1 . 4 6 0 . 0 0 0}$ \\
\hline Pendapatan (2-1) & $\mathbf{3 1 . 6 9 0 . 0 0 0}$ \\
\hline
\end{tabular}

\section{KESIMPULAN DAN SARAN}

\section{Kesimpulan}

1. Peningkatan pengetahuan dan keterampilan anggota kelompok tani dalam mengelola lahan. Keahlian dan pengetahuan yang dimiliki oleh kelompok tani saat ini sudah meningkat dan berpengaruh terhadap produktivitas serta hasil pertanian

2. Penyuluhan dan pendampingan intensif yang di lakukan oleh tim membuat kelompok tani mengalami peningkatan wawasan dalam bertani menjadi lebih meningkat, baik jumlah maupun kualitas.

3. Keterbatasan dalam pendanaan membuat petani merasa segan untuk mengelola lahan dan memilih untuk mencari pekerjaan lain. Tapi dengan adanya bantuan pendanaan dari DP2M DIKTI membuat pengolahan lahan boleh terlaksana dengan baik dan kelompok tani bisa mengembangkan usaha pertanian dan pemasarannya.

4. Rasa segan mengolah lahan dan keinginan untuk beralih profesi bukan lagi menjadi hal yang utama dikarenakan adanya berbagai bantuan berupa bibit, peralatan pertanian, perlengkapan, bantuan pendanaan, penyuluhan dan pendampingan oleh tim pelaksana PKM untuk mengembangkan usaha pertanian sehingga pendapatannya meningkat.

5. Pembekalan pengetahuan tentang manajemen dan kelembagaan kelompok membuat kelompok tani mampu mengelola usahataninya dengan lebih baik.

\section{Saran}

Melihat keberhasilan program kemitraan masyarakat ini yang membuat masyarakat dalam hal ini kelompok tani lebih berkembang dalam segi pengetahuan, keterampilan dan juga kesejahteraan diharapkan program seperti ini dapat terus berlanjut sehingga lebih banyak lagi kelompok masarakat yang bisa terbantu.

\section{DAFTAR PUSTAKA}

Anonimous, 2017. Data harga kebutuhan pokok. Pusat Informasi Harga Barang Strategis (PIHBS) Sulawesi Utara.

Anonimous, 2017. Data Peta Kecamatan Tomohon Selatan. Google Indonesia. 